\title{
Elderly Woman with Headache and Lagophthalmos with Visual Loss
}

Utaro Anazawa ${ }^{1}$, Kazuhiro Omura ${ }^{1,2 *}$ and Yasuhiro Tanaka ${ }^{1}$

${ }^{1}$ Department of Otorhinolaryngology, Dokkyo Medical University Koshigaya Hospital, Japan

${ }^{2}$ Department of Otorhinolaryngology, The Jikei University School of Medicine, Japan

Submission: November 17, 2017; Published: December 09, 2017

*Corresponding author: Kazuhiro Omura, Postal code: 343-0845, 2-1-50 Minamikoshigaya Koshigaya-si, Saitama, Japan, Tel: +81-48-965-1111; Email: kazuhiro.omura@gmail.com

\section{Introduction}

A 78-year-old woman presented with headache, a six-day history of swollen right eye, and a four-day history of gradually worsening visual disturbance, along with spontaneous vomiting. A physical examination showed severe swelling of her right eye with inflammation and severe edema of the conjunctiva, lagophthalmos, cataract ulceration, and exophthalmic ophthalmoplegia (Figure 1A \& 1B). A visual accuracy test could not be performed. Computed tomography revealed a superior subperiosteal orbital abscess with the right eye protruding1.8 $\mathrm{cm}$ anterior to the left eye (Figure 2A \& 2B).

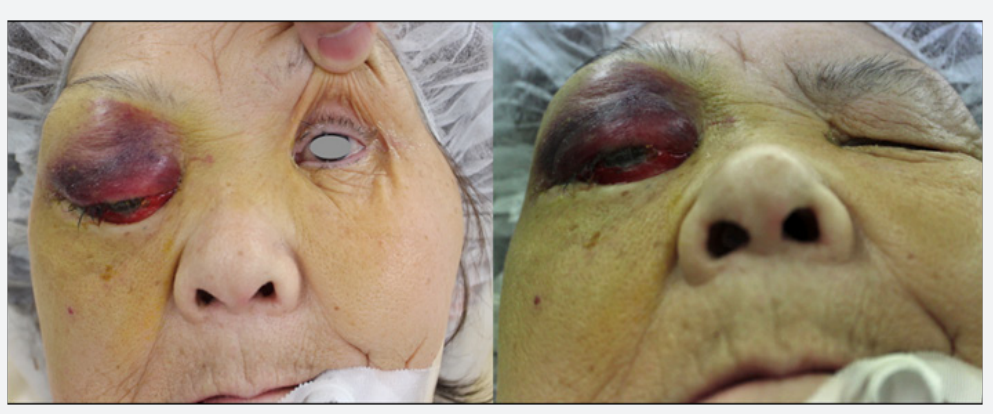

Figure 1: Physical findings. A.B. Right lagophthalmos with swollen eyelid and conjunctivaledema.

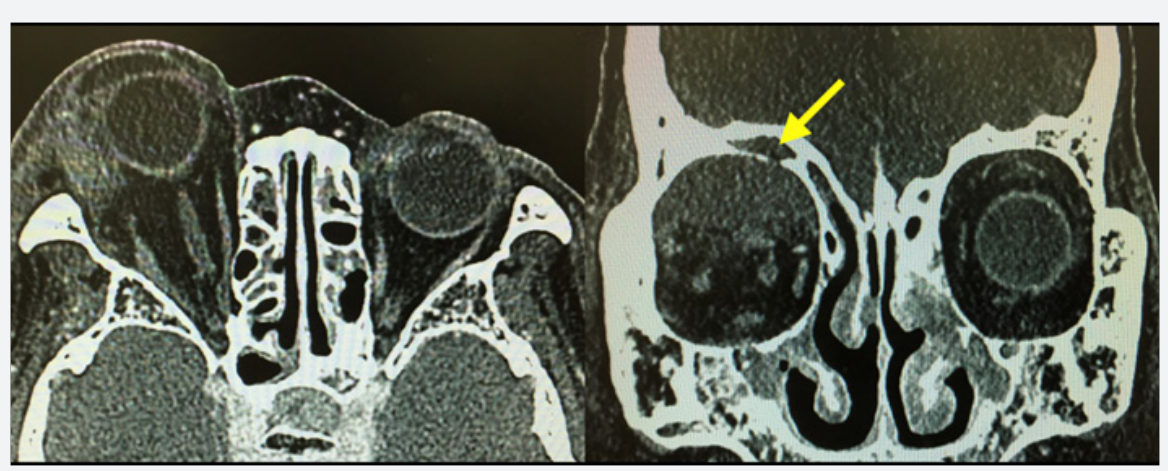

Figure 2: Computed tomography findings on initial presentation. A. Axial view. The right eyeball was protruding $1.8 \mathrm{~cm}$ anterior to the left eyeball; B. Coronal view. Periosteal abscess with bony defect of the roof of orbit (yellow arrow) with frontal sinusitis. 


\section{Diagnosis}

A superior subperiosteal orbital abscess (SSPOA) is a collection of purulent material between the periorbit and the superior bony orbital wall, and is typically a complication of frontal sinusitis. Orbital complications can result in permanent blindness or death if not treated promptly and appropriately. Immediate attention and proper management are required to prevent fatal complications [1]. Abscesses in older patients usually contain mixtures of aerobic and anaerobic microbes and are more likely to require drainage than those in children. Surgical drainage is particularly recommended for SSPOAs

because of the risk of intracranial infection [2]. The visual loss associated with orbital cellulitis is thought to result from optic neuritis as a result of inflammation from nearby infection, ischemia resulting from thrombophlebitis along the orbital veins, and pressure resulting in central retinal artery occlusion [3].

This work is licensed under Creative Commons Attribution 4.0 License

DOI: $10.19080 /$ JOJO.2017.05.555674
The patient underwent emergent surgical drainage with combined approach. The inflammation improved immediately postoperatively, but she did not regain vision in her right eye.

\section{Conflict of Interest}

The authors confirm no relevant conflicts of interest to this work, and no relevant financial disclosures to report.

\section{References}

1. Gavriel H, Jabrin B, Eviatar E (2016) Management of superior subperiosteal orbital abscess. Eur Arch Otorhinolaryngol 273(1): 145150.

2. Dewan MA, Meyer DR, Wladis EJ (2011) Orbital cellulitis with subperiosteal abscess: demographics and management outcomes. Opthal Plast Reconstr Surg 27(5): 330-332.

3. Patt BS, Manning SC (1991) Blindness resulting from orbital complications of sinusitis. Otolaryngol Head Neck Surg 104(6): 789.

\section{Your next submission with Juniper Publishers} will reach you the below assets

- Quality Editorial service

- Swift Peer Review

- Reprints availability

- E-prints Service

- Manuscript Podcast for convenient understanding

- Global attainment for your research

- Manuscript accessibility in different formats ( Pdf, E-pub, Full Text, Audio)

- Unceasing customer service

Track the below URL for one-step submission https://juniperpublishers.com/online-submission.php 